\title{
Inovasi mesin pengaduk kosentrat pakan ternak
}

\author{
Junil Adri ${ }^{1)^{*}}$, Nelvi Erizon ${ }^{2)}$, Bulkia Rahim ${ }^{3)}$ \\ ${ }^{123}$ Jurusan Teknik Mesin, Fakultas Teknik, Universitas Negeri Padang, Jl. Prof. Dr. Hamka Air Tawar, Kota \\ Padang, Indonesia \\ juniladri@ft.unp.ac.id*; nelvierizon@ft.unp.ac.id; bulkiarahim@ft.unp.ac.id;
}

\begin{abstract}
ABSTRAK
Penelitian ini bertujuan untuk menghasilkan inovasi terhadap pakan ayam. Tingginya harga pakan ayam pabrikan menjadi permasalahan mendasar bagi peternak ayam. Pemanfaatan lindah dan potensi kedaerahan dapat menjadi solusi untuk pembuatan pakan secara mandiri. Dalam pengolahan pakan, dibutuhkan beberapa proses diantaranya penggilingan, pencampuran dan pencetakan. Penulis merancang sebuah mesin untuk mendukung pengolahan pakan berupa mesin pencampur dengan sistem cakram putar. Pemilihan desain ini didasarkan pada jenis konsentrat dan bahan dasar berupa feed powder. Dengan adanya pakan yang berkualitas diharapkan dapat meningkatkan produktivitas sektor peternakan di Indonesia. Penelitian ini merupakan penelitian eksperimen dengan indikator efektifitas inovasi dan kualitas pakan ternak. Dalam desain mesin target adalah efisiensi finansial, efisiensi operasional dan efisiensi kuantitas. Hasil penelitian ini menunjukkan bahwa mesin pencampur dengan sistem cakram berputar sangat efektif digunakan untuk mencampur bahan baku pakan ayam dengan konsentratnya sebelum mencetak pakan ayam. Untuk mencampur $25 \mathrm{~kg}$ bahan pakan ayam hanya membutuhkan waktu 134 detik. Inovasi ini dengan sasaran peternak skala mikro dengan keterbatasan biaya pengadaan pakan.
\end{abstract}

Kata kunci: Pakan Ternak, Mesin Pengaduk, Mesin Pengolah Pakan, dan Teknologi Tepat Guna.

\begin{abstract}
This study aims to produce innovations in chicken feed. The high price of factory chicken feed is a fundamental problem for chicken farmers. Utilization of lidah and regional potential can be a solution for independent feed manufacture. In feed processing, it takes several processes including milling, mixing and printing. The author designed a machine to support feed processing in the form of a mixing machine with a rotary disc system. The selection of this design is based on the type of concentrate and the basic material in the form of feed powder. With the existence of quality feed is expected to increase the productivity of the livestock sektor in Indonesia. This research is an experimental study with indicators of innovation effectiveness and animal feed quality. In machine design the targets are financial efficiency, operational efficiency and quantity efficiency. The results of this study indicate that a mixing machine with a rotating disc system is very effective in mixing chicken feed raw materials with the concentrate before printing chicken feed. to mix $25 \mathrm{~kg}$ of chicken feed ingredients only takes 134 seconds. This innovation targets micro-scale farmers with limited feed procurement costs.
\end{abstract}

Keywords: Animal Feed, Mixing Machines, Feed Processing Machines, and Appropriate Technology.

diunggah: Juli 2021, direvisi: November 2021, diterima: Desember 2021, dipublikasi: Desember 2021 Copyright (c) 2021 Junil Adri, Nelvi Erizon, Bulkia Rahim

This is an open access article under the CC-BY license

\section{PENDAHULUAN}

Komuditas ternak ayam menjadi sektor yang banyak dilakoni pada masyarakat pedesaan. (Dewanti \& Sihombing, 2012). Komuditas hasil peternakan menjadi sumber protein hewani dengan harga terjangkau bagi semua lapisan masyarakat (Ratnasari, Sarengat, \& Setiadi, 2015). Peningkatan pertumbuhan penduduk dan ilmu pengetahuan, masyarakat telah banyak sadar akan kebutuhan gizi. Efek dari gaya hidup dan kesadaran akan asupan 
makanan yang berkualitas memberikan dampak pada tingginya permintaan akan kebutuhan protein daging dan telur (I. R. Rahmawati, Muksin, \& Rizal, 2016).

Berdasarkan sebuah pengamatan yang dilakukan Utomo memperkirakan pada tahun 2035 total jumlah penduduk Indonesia menjadi dua kali lipat atau \pm 400 juta jiwa (Utomo et al., 2021). Peningkatan ini tentunya juga mempengaruhi kebutuhan akan telur serta daging ayam sebagai makanan sumber protein yang ekonomis. Tingginya kebutuhan daging dan telur tentunya juga memberikan dampak pada kebutuhan pakan ayam sebagai penghasil daging dan telur (Abidin, 2003). Tingginya tingkat kebutuhan akan menghadirkan usaha peternakan semakin berkembang. Kebutuhan akan pakan dan kualitas gizi pakan menjadi sektor potensial yang bisa dikembangkan.

Pada tahun 2018 peneliti telah melakukan penelitian yang didanai oleh PNBP UNP tetang pengembangan inovasi tentang pemanfaatan limbah cangkang telur dan keong mas menjadi konsentrat pakan ayam. Penelitian ini telah selesai sesuai dengan target capaian awal yang direncanakan. Peneliti membuat alat penghancur konsentrat dan mesin pencetak pakan dengan sistem ayakan bertingkat. Namun dalam pelaksanaan pengolahan pakan peneliti menemukan permasalahan berupa kesulitan dalam pengadukan kosentrat dengan bahan dasar berupa bekatul. Pencampuran kosentrat dengan bahan dasar ini cukup sulit karena pencampuran antara kosentrat dengan bahan dasar harus merata (Adri \& Rahim dan Nelvi Erizon, 2019).

Berdasarkan kesulitan yang peneliti temukan, peneliti berkeinginan merancang sebuah alat pengaduk kosentrat dengan bahan dasar bekatul untuk menjadikan pakan ayam yang bernilai gizi tinggi. Alat yang akan dibuat ini diharapkan mampu bersinergi dengan alat yang telah dibuat pada tahun sebelumnya sehingga apabila dihilirisasi hasil penelitian ini bisa dimanfaatkan seutuhnya oleh para peternah tingkat kecil dan menengah.

Konsep alat pengaduk kosentrat dan bahan dasar pada pakan ayam ini adalah dengan sistem piringan berpuptar. Piringan pengaduk merupakan wadah utama dalam proses pengadukan. Piringan ini akan dilengkapi blade sebagai penahan adonan supaya tercampur rata. Piringan pengaduk akan digerakan oleh motor listrik 2 HP yang di transmisi pada gearbox. Dengan mekanisme ini diharapkan alat ini akan mampu mengaduk kosentrat dengan bahan dasar secara merata, untuk selanjutnya masuk pada proses pencetakan sesuai dengan yang telah dikerjakan pada tahun sebelumnya. Kombinasi dari hasil penelitian ini akan menjadikan output pakan ternah siap konsumsi bagi ayam.

Tingginya harga pakan pabrikan menjadikan banyak peternak kecil dan menengah mencari pakan alternatif untuk ayam mereka. Inovasi ini akan menjawab permasalahan yang dihadapi para peternak. Bila dibandingkan $1 \mathrm{Kg}$ pakan pabrikan dihargai Rp. 15.000,sementara untuk $1 \mathrm{Kg}$ Bekatul bisa didapat dengan harga Rp.2.000,- sementara untuk konsentrat pakan bisa menggunakan limbah cangkang telur bisa didapatkan di kafe, tempat produksi kue dan keong mas yang bisa didapatkan di sawah-sawah yang mana keong ini merupakan hama padi bagi para petani. Besarnya selisih harga ini menjadi peluang bagus untuk dimanfaatkan dengan menciptakan pakan ternak murah. Alat yang akan dibuat ini melengkapi seluruh proses pengolahan pakan ayam, sehingga hasil penelitian dapat di manfaatkan langsung oleh peternak kecil dan menengah.

Pakan ternak adalah sumber protein dan energi yang dibutuhkan ternak dalam proses tumbuh dan berkembangnya. Dasar dari pakan ternak biasanya bersumber dari tumbuhan dan hewani. Dalam pembentukan pakan ternak, tumbuhan atau hewan yang diberikan biasanya diolah dalam bentuk kosentrat. Kompoisisi kosentrat diatur sesuai dengan kebutuhan gizi dalam proses tumbuh kembang peternakan yang dilakukan (Astuti, 2012). Pada peternakan ayam, bobot gizi atau nutrisi mendominasi pada kebutuhan protein. Tingkat kebutuhan nutrisi ayam juga dibedakan berdasarkan umurnya. Kebutuhan nutrisi ayam anakan, ayam remaja dan ayam dewasa memiliki kebutuhan nutrisi yang berbeda (Gusnadi \& Razak, 2018). 


\section{Kosentrat pada pakan ayam}

Dalam penelitian ini, kosentrat yang digunakan adalah cangkang telur dan keong mas. Penggunaan cangkang telur dan keong mas ini dari banyaknya literatur yang mengungkapkan tingginya kadar kalsium dan protein yang terkandung dan sesuai dengan kebutuhan pakan ayam.

Secara umum struktur cangkang telur terdiri atas tiga lapisan, yaitu lapisan kutikula, lapisan spons, dan lapisan lamellar (Kusumawati, 2019). Lapisan kutikula merupakan permukaan terluar yang mengandung sejumlah protein. Lapisan spons dan lamelar membentuk matriks yang dibentuk oleh serat protein yang terikat oleh kalsium karbonat dalam cangkng telur. Cangkang telur mewakili $11 \%$ dari total bobot telur dan tersusun oleh kalsium karbonat (94\%), kalsium fosfat (1\%), material organik (4\%), dan magnesium karbonat (1\%) (W. A. Rahmawati \& Nisa, 2014).

Sebagian besar kalsium dalam cangkang telur mengendap dalam kurun waktu 16 jam. Tidak ada ayam yang dapat menkonsumsi kalsium begitu cepat untuk memenuhi tuntutan ini (Majedi, Mahanani, \& Triswari, 2013). Sebagai gantinya, kalsium dipasok oleh massa-massa tulang khusus yang terdapat pada tulang ayam, yang mengumpulkan cadangan kalsium dalam jumlah besar untuk pembentukan cangkang. Jika ayam diberi pakan rendah kalsium, cangkang telurnya menjadi semakin tipis, ayam dapat menggunakan $10 \%$ dari jumlah seluruh kalsium dalam tulangnya hanya untuk membentuk sebutir telur. Bila pakannya terus-menerus rendah kalsium, produksi telur pada akhirnya akan berhenti. Kandungan kalsium karbonat dari cangkang telur ayam yang dikeringkan dengan penempelan albumin (Susanto, Atmono, \& Natalina, 2017) dapat dilihat pada tabel di bawah ini:

Tabel 1. Komposisi nutrisi cangkang telur ayam

\begin{tabular}{llll}
\hline Nutrisi & Kandungan (\% Berat) & Nutrisi & Kandungan (\% Berat) \\
\hline Air & $29-35$ & Glisin & $0,37-0,41$ \\
Protein & $1,4-4$ & Histidin & $0,25-0,30$ \\
Kalsium & $35,1-36,4$ & Isoleusin & 0,34 \\
CaCO3 & 90,9 & Leusin & 0,57 \\
Fosfor & 0,12 & Lisin & 0,37 \\
Magnesium & $0,37-0,40$ & Metionin & $0,28-0,29$ \\
Kalium & $0,10-0,13$ & Phenilalanin & $0,38-0,46$ \\
Sulfur & $0,09-0,19$ & Prolin & $0,54-0,62$ \\
Alanin & 0,45 & Serin & $0,64-0,65$ \\
Arginin & $0,56-0,57$ & Thereonin & $0,45-0,47$ \\
Asam aspartate & $0,83-0,87$ & Tirosin & $0,25-0,26$ \\
Cistin & $0,37-0,41$ & Valin & $0,54-0,55$ \\
\hline
\end{tabular}

Untuk memenuhi kadar protein pada pakan ayam ditambahkan dengan kosentrat keong mas. Keong mas cukup potensial sebagai sumber protein hewani (Hendrawati, 2011). Keong mas yang merupakan hama petani padi sangat mudah ditemukan di sawah. Keong mas memiliki kandungan gizi lain yakni kalori dan karbohidrat. Keong mas juga mengandung vitamin dan mineral yang dibutuhkan oleh tubuh. Beberapa mineral yang ditemukan dalam daging keong mas antara lain kalsium, natrium, kalium, fosfor, magnesium, seng, dan zat besi. Tabel berikut menunjukkan kandungan mineral daging keong mas (Ella, Nurhayu, \& Pasambe, 2016; Fadly, 2016). 
Tabel 2. Kandungan mineral keong mas

\begin{tabular}{llll}
\hline $\begin{array}{c}\text { Komposisi mineral } \\
\text { makro }\end{array}$ & \multicolumn{1}{c}{$\begin{array}{c}\text { Kadar (bk) } \\
(\mathrm{mg} / 100 \mathrm{gr})\end{array}$} & $\begin{array}{c}\text { Komposisi mineral } \\
\text { mikro }\end{array}$ & $\begin{array}{c}\text { Kadar (bk) } \\
(\mathrm{mg} / 100 \mathrm{gr})\end{array}$ \\
\hline Kalsium & 7593,81 & Besi & 44,16 \\
Natrium & 620,84 & Seng & 20,57 \\
Kalium & 824,84 & Selenium & Tidak terdeteksi \\
Fosfor & 1454,32 & Tembaga & Tidak terdeteksi \\
Magnesium & 238,05 & & \\
\hline
\end{tabular}

Komposisi kimia keong mas dinyatakan dalam persentase dari unsur-unsur air, abu, protein, dan lemak. Komposisi kimia bahan baku sangat bervariasi, tergantung pada ukuran, kelamin, tingkat kematangan seksual, maupun waktu penangkapan biota. Komposisi kimia daging keong mas disajikan pada tabel berikut:

Tabel 3. Komposisi kimia keong mas

\begin{tabular}{lccc}
\hline Komposisi kimia & $\begin{array}{c}\text { Nurjanah et al } \\
(1996)\end{array}$ & Susanto (2010) & Pambudi (2011) \\
\hline Kadar air & $84,70(\mathrm{bb})$ & $81,19(\mathrm{bb})$ & $81,50(\mathrm{bb})$ \\
Kadar protein & $9,33(\mathrm{bb})$ & $10,30(\mathrm{bb})$ & $7,58(\mathrm{bb})$ \\
Kadar lemak & $0,91(\mathrm{bb})$ & $0,51(\mathrm{bb})$ & $2,10(\mathrm{bb})$ \\
Kadar abu & $1,43(\mathrm{bb})$ & $4,07(\mathrm{bb})$ & $9,03(\mathrm{bb})$ \\
\hline
\end{tabular}

\section{Mesin pengaduk}

Mesin pengaduk (mixer) merupakan salah satu alat pencampur dalam sistem emulsi sehingga menghasilkan suatu dispersi yang seragam atau homogen. Proses Mixer merupakan proses mencampurkan satu atau lebih bahan dengan menambahkan satu bahan ke bahan lainnya sehingga membuat suatu bentuk yang seragam dari beberapa konstituen baik cair - padat, padat - padat, maupun cair - gas. Komponen yang jumlahnya lebih banyak disebut fasa kontinyu dan yang lebih sedikit disebut fasa disperse.

Dalam penelitian ini, peneliti mencoba mendesain salah satu model pengaduk yang sesuai dengan tujuan penelitian, yaitu mencapurkan kosentrat pakan dengan bahan dasar (bekatul) (Basyir et al., 2019). Karakteristik bahan yang berupa serbuk menjadi pertimbangan peneliti dalam melakukan rancangan (Adri \& Refdinal, 2018). Konsep alat pengaduk kosentrat dan bahan dasar pada pakan ayam ini adalah dengan sistem piringan berpuptar. Piringan pengaduk merupakan wadah utama dalam proses pengadukan. Piringan ini akan dilengkapi blade sebagai penahan adonan supaya tercampur rata. Piringan pengaduk akan digerakan oleh motor listrik 1 HP yang di transmisi pada gearbox. Dengan mekanisme ini alat ini akan mampu mengaduk kosentrat dengan bahan dasar secara merata, untuk selanjutnya masuk pada proses pencetakan sesuai dengan yang telah dikerjakan pada tahun sebelumnya. Kombinasi dari hasil penelitian ini akan menjadikan output pakan ternah siap konsumsi bagi ayam.

\section{METODE}

Penelitian ini merupakan preliminary research yang mengkaji desain, uji efektivitas dan anlisis output. Pendekatan yang dilakukan dalam penelitian ini adalah bersifat investigasi dan survei, yang dilaksanakan dengan teknik dan metode yang disesuaikan pada tujuan penelitian. Penelitian ini dilaksanakan dengan beberapa tahapan yaitu:

\section{Tahapan analisis permasalahan}

Tahapan analisis permasalahan adalah tahapan mendiskusikan permasalahan yang ditemukan dengan dosen ahli. Dari diskusi yang akan dilakukan akan didapatkan usulanusulan design alat yang akan dibuat. 


\section{Tahapan pembuatan design}

Tahapan pembuatan design merupakan tahapan pembuatan gambar desing alat yang akan dibuat. Pembuatan gambar design dilakukan dengan menggunakan sofware Autocad 2017. Gambar rancangan ini akan dilengkapi dengan dimensi dari masing-masing komponen.

\section{Tahapan pembuatan alat}

Tahapan pembuatan alat akan dilaksanakan di workshop Teknik Mesin. Pembuatan alat ini membutuhkan proses pengelasan, pembubutan, proses penggerindaan, dan proses finishing.

\section{Tahapan anlisis peforma}

Tahapan analisis peforma dilaksanakan dengan dua indikator yaitu waktu dan kualitas pencampuran. Adapun flow chart metodologi penelitian yang digunakan sebagai berikut:

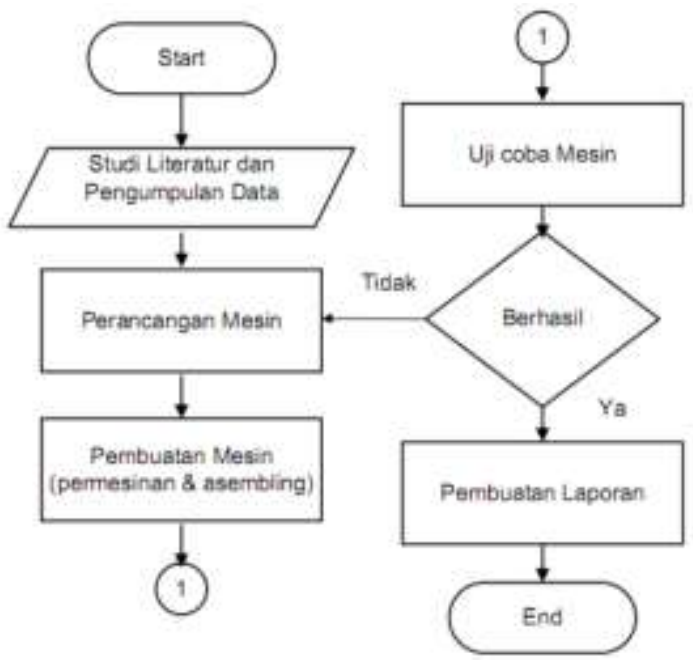

Gambar 1. Flow chart pelaksanaan penelitian

\section{HASIL DAN PEMBAHASAN}

\section{Analisis volume piringan pengaduk}

Piringan pengaduk yang berbentuk silinder dengan diameter $120 \mathrm{~cm}$ dan tinggi 30 $\mathrm{cm}$. Untuk menentukan kapitas pengadukan maka ditentukan volume dari piringan pengaduk.
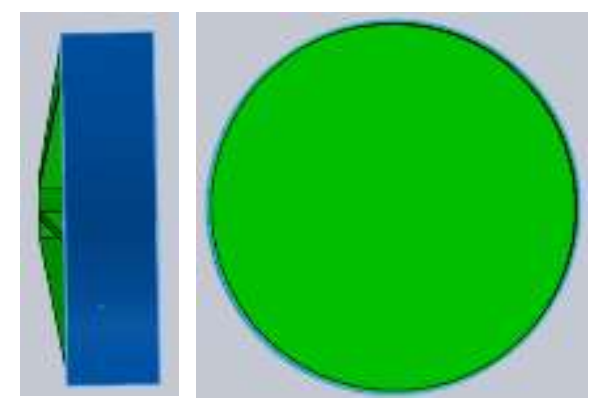

Gambar 2. Piringan pengaduk

Volume Pengaduk $=\pi x r^{2} x t$

Volume Pengaduk $=3,14 \times 60^{2} \times 30$

Volume Pengaduk $=339.12 \mathrm{~cm}^{3}$ 


\section{Analisis daya motor}

Motor yang digunakan sebagai penggerak adalah motor AC (Ambiyar, Syahri, \& Adri, 2019). Untuk menentukan kesesuaian motor yang digunakan maka diperlukan analisis. Putaran yang dibutuhkan dalam proses pengadonan pakan adalah $150 \mathrm{Rpm}$.

$V=\frac{\pi \cdot d \cdot n}{60}$

$V=\frac{3,14.30 .150 \mathrm{rpm}}{60}=235 \mathrm{~cm} / \mathrm{sec}$
$V=2,35 \mathrm{~m} / \mathrm{sec}$

Putaran motor yang dibutuhkan adalah:

$\mathrm{P}=\mathrm{F} . \mathrm{V}$

$\mathrm{F}=\delta . \mathrm{A}$

$\mathrm{F}=83,6 \mathrm{~kg} / \mathrm{m}^{2} \cdot 7,63 \mathrm{~m}^{2}=638,29 \mathrm{~kg}$

$\mathrm{P}=638,29.2,35 \mathrm{~m} / \mathrm{sec}=1499,98 \mathrm{~kg} \cdot \mathrm{m} / \mathrm{sec}$

Spesifikasi motor listrik yang digunakan dalam perencanaan adalah :

Daya $=1500 \mathrm{~kg} \cdot \mathrm{m} / \mathrm{det}=1,5 \mathrm{~kW}=2 \mathrm{Hp}$

Putaran Motor $1450 \mathrm{rpm}$

\section{Perancangan poros}

Bahan poros puli adalah baja karbon S $55 \mathrm{C}$ kekuatan tarik $\sigma_{\mathrm{B}}=891 \mathrm{~N} / \mathrm{mm}^{2}$

Momen Puntir $\quad \mathrm{T}_{1}(\mathrm{Nmm})$

$\mathrm{dp}_{1}=$ Diameter poros $\left(\mathrm{dp}_{1}\right)$

$\mathrm{Kt}=$ Faktor koreksi puntiran diambil 2

$\mathrm{Cb}=$ Faktor lentur diambil 1,5

$d p_{1}=\left(\frac{\mathbf{5}, \mathbf{1}}{\tau_{B}} k_{t} \cdot C_{b} T_{1}\right)^{\frac{1}{3}}$

$d p_{1}=\left(\frac{5,1}{11} 2 \times 1,5 \times 27, x 393,7\right)^{\frac{1}{3}}$

$d p_{1}=38.101,17^{\frac{1}{3}}$

$d p_{1}=23,674 \mathrm{~mm}$

Jadi diameter poros yang digunakan adalah $24 \mathrm{~mm}$.

\section{Analisis puli dan sabuk}

a. Perhitungan Puli

$$
\begin{aligned}
i & =\frac{n_{1}}{n_{2}} \ldots \ldots \ldots \ldots \ldots \ldots \\
i & =\frac{1450}{800}=1,8
\end{aligned}
$$

Daya rencana $(\mathrm{Pd})$

$P d=1,5 \times 1,5=2,25 \mathrm{~kW}$

Diameter lingkaran jarak bagi untuk puli kecil dp dan puli besar $\mathrm{Dp}_{1}$ dan $\mathrm{Dp} \mathrm{p}_{2}$

$\mathrm{Dp}_{1}=67$

$\mathrm{Dp}_{2}=\mathrm{i} \times \mathrm{d}_{\mathrm{p}}=1.8 \times 67=120 \mathrm{~mm}$ 
b. Perhitungan Sabuk

Kecepatan Linier Sabuk - V (m/s )

$$
\begin{aligned}
& V=\frac{\pi x d p \times n}{60 \times 1000 \ldots \ldots \ldots \ldots} \\
& V=\frac{3,14 \times 67 \times 1450}{60 \times 1000} \\
& V=5,08 \mathrm{~m} / \mathrm{s}
\end{aligned}
$$

Panjang Keliling Suduk dari puli 1 ke puli 2 (L)

$$
\begin{aligned}
& L=2 C+\frac{\pi}{2}\left(D p_{1}+D p_{2}\right)+\frac{1}{4 C}\left(D p_{2}-D p_{1}\right)^{2} \\
& L=2 \times 204+\frac{\pi}{2}(67+120)+\frac{1}{4 \times 204}(120-67)^{2} \\
& L=705,03 \mathrm{~mm}
\end{aligned}
$$

Dari hasil perhitungan panjang keliling sabuk $921.26 \mathrm{~mm}$ didapat $\mathrm{L}=711 \mathrm{~mm}$, jenisnya $3 \mathrm{~V}-280$ :

$b=2 L-3,14\left(D p_{2}-D p_{1}\right)$

$b=2 \times 711-3,14(120-67)$

$b=822,88 \mathrm{~mm}$

Jarak Sumbu Poros

$\boldsymbol{C}=\frac{\boldsymbol{b}+\sqrt{\boldsymbol{b}^{2}-\mathbf{8}\left(D p_{2}-D p_{1}\right)^{2}}}{\mathbf{8}}$

$C=\frac{822,88+\sqrt{822,88^{2}-8(120-67)^{2}}}{8}$

$C=181,65 \mathrm{~mm}$

Setelah analisis, pembuatan gambar dilakukan menggunakan autocad.

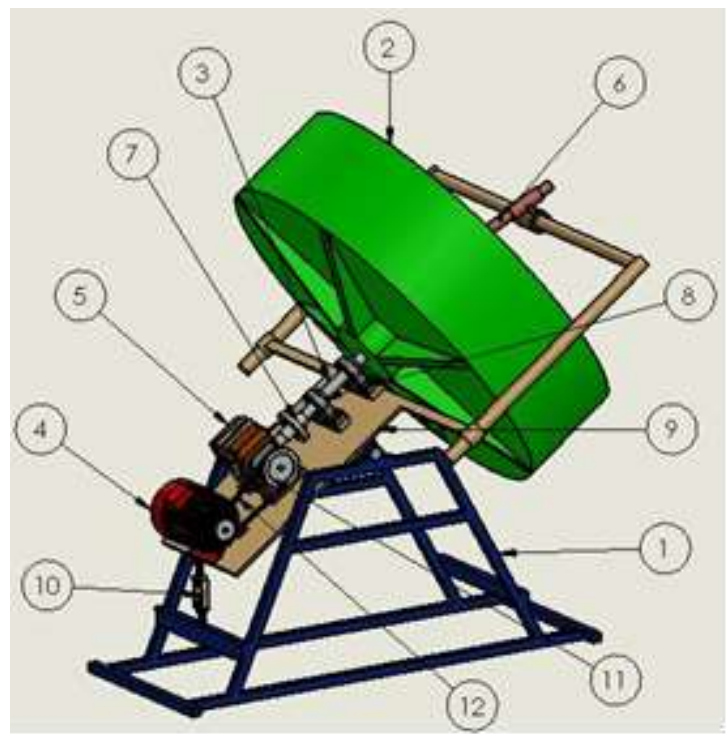

Gambar 3. Design mesin pengaduk 
Keterangan:
1. Rangka
7. Kopling
2. Piringan pengaduk
8. Bantalan
3. Poros
9. Lengan Pengaduk
4. Motor penggerak
5. Reduser
10. Mekanisme Pengarah
6. Tuas Pengaduk
11. Pully
12. Sabuk

Pembuatan mesin pengaduk sistem piringan putar dilakukan di bengkel fabrikasi jurusan Teknik Mesin. Proses pembuatan mesin pengaduk membutuhkan waktu satu bulan.

Pengujian mesin dilakukan untuk mengetahui apakah pencampuran sudah menghasilkan performa sesuai dengan yang direncanakan. Bahan yang digunakan dalam pencampuran yaitu dedak, tepung kulit telur, tepung keong sawah. Pengujian mesin pencampur pakan ayam dilakukan sebanyak 5 kali percobaan dengan bahan yang sama tetapi bobot yang berbeda.

Berikut hasil pengujian yang telah dilakukan dapat dilihat pada tabel 4.

Tabel 4. Tabulasi hasil penelitian

\begin{tabular}{ccccc}
\hline No & Dedak & Cangkang Telur & Keong Sawah & Waktu Pencampuran \\
\hline 1 & $5 \mathrm{~kg}$ & $0,5 \mathrm{~kg}$ & $0,5 \mathrm{~kg}$ & 37 seconds \\
2 & $10 \mathrm{~kg}$ & $1 \mathrm{~kg}$ & $1 \mathrm{~kg}$ & 60 seconds \\
3 & $15 \mathrm{~kg}$ & $1,5 \mathrm{~kg}$ & $1,5 \mathrm{~kg}$ & 88 seconds \\
4 & $20 \mathrm{~kg}$ & $2 \mathrm{~kg}$ & $2 \mathrm{~kg}$ & 114 seconds \\
5 & $25 \mathrm{~kg}$ & $2,5 \mathrm{~kg}$ & $2,5 \mathrm{~kg}$ & 134 seconds \\
\hline
\end{tabular}

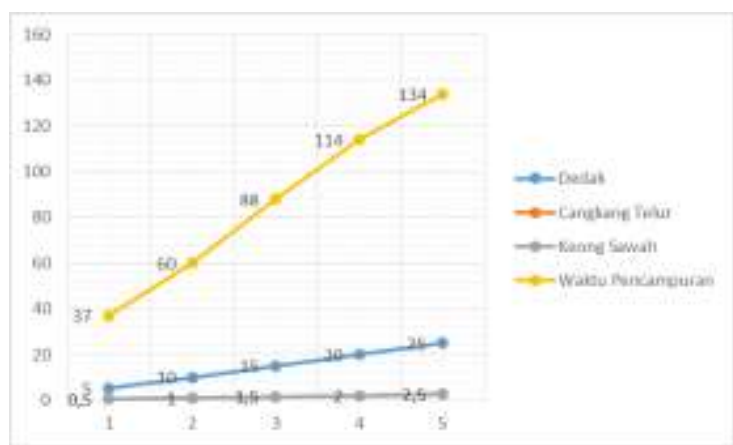

Gambar 4. Grafik proses pencampuran

Hasil pengujian menunjukkan bahwa mesin pengaduk mampu mengaduk secara homogen selama 37 detik untuk percobaan pertama dimana dedak padi sebanyak $5 \mathrm{~kg}$, tepung kulit telur sebanyak $0,5 \mathrm{~kg}$, dan tepung keong sawah sebanyak $0,5 \mathrm{~kg}$. Percobaan kedua dilakukan pengadukan hingga homogen selama 1 menit yang terdiri dari $10 \mathrm{~kg}$ dedak padi, 1 $\mathrm{kg}$ tepung cangkang telur, dan $1 \mathrm{~kg}$ bubuk cangkang keong. Indikator bahwa konsentrat telah tercampur merata adalah perubahan warna bahan abu-abu. Percobaan ketiga dilakukan pencampuran homogen selama 1 menit 28 detik dimana dedak padi sebanyak $15 \mathrm{~kg}$, tepung

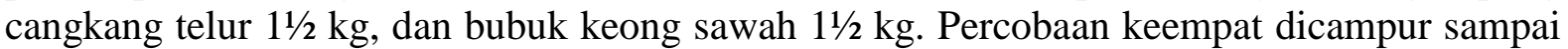
homogen selama 1 menit 54 detik dimana dedak padi $20 \mathrm{~kg}$, tepung cangkang telur $2 \mathrm{~kg}$, dan bubuk bekicot $2 \mathrm{~kg}$. Percobaan kelima adalah pencampuran hingga homogen selama 2 menit 14 detik yang terdiri dari $25 \mathrm{~kg}$ bekatul, $2^{1 / 2} \mathrm{~kg}$ tepung cangkang telur, dan $2 \frac{1}{2} \mathrm{~kg}$ tepung keong. Berdasarkan hasil uji coba tersebut dapat dikatakan bahwa mesin berfungsi sesuai dengan yang diharapkan yaitu mampu mengaduk pakan ternak secara efektif.

Visualisasi hasil pengujian sampai terjadi pencampuran yang homogen untuk pakan ayam sesuai Gambar 5 dan 6. 


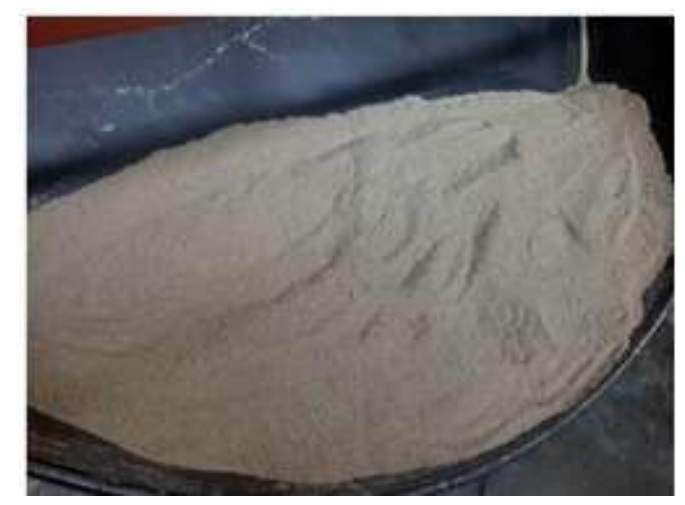

Gambar 5. Proses pengadukan

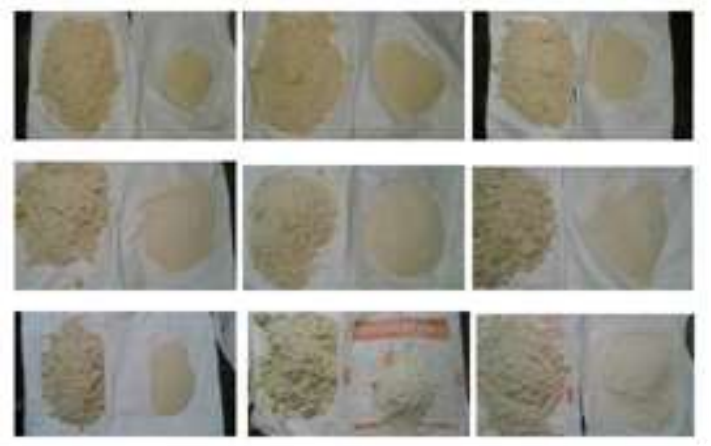

Gambar 6. Hasil pengadukan

\section{SIMPULAN}

Hasil pengujian menunjukkan bahwa mesin pengaduk ini mampu mencampur hingga homogen dengan waktu yang singkat. Hasil ini dapat menjadi pilihan menciptakan pakan ternak secara mandiri. Tingginya harga pakan ternak yang berdampak pada besarnya biaya pakan yang dibutuhkan peternak dalam proses pembeasaran ayam tidak lagi menjadi masalah dengan inovasi pakan ternak dengan memamfaatkan sumber daya alam sekitarnya.

\section{DAFTAR PUSTAKA}

Abidin, I. Z. (2003). Meningkatkan Produktivitas Ayam Ras Petelur: Agromedia.

Adri, J., \& Rahim2 danNelviErizon, B. (2019). Inovasi Mesin Pengolahan Pakan Dengan Konsentrat Limbah Cangkang Telur Dan Keong Sawah. Jurnal Sains dan Teknologi: Jurnal Keilmuan dan Aplikasi Teknologi Industri, 19(1), 1-10.

Adri, J., \& Refdinal, R. (2018). Aplikasi teknologi tepat guna thereser multiguna untuk petani padi daerah perbatasan dharmasraya. Jurnal Sains dan Teknologi: Jurnal Keilmuan dan Aplikasi Teknologi Industri, 18(2), 53-59.

Ambiyar, A., Syahri, B., \& Adri, J. (2019). Aplikasi Teknologi Tepat Guna Pada Alat Tanam Jagung di Kenagarian Limabanang Kecamatan Suliki Kabupaten 50 Kota Sumatera Barat (Appropriate Technology Application in Corn Planting in Kenagarian Limabanang Kecamatan Suliki Kabupaten 50 Kota Sumatera Barat). Jurnal Aplikasi IPTEK Indonesia, 3(1), 48-55.

Astuti, N. (2012). Kinerja ayam kampung dengan ransum berbasis konsentrat broiler. Jurnal Agrisains, 3(5). 
Basyir, A., Sinaga, P. A., Muldani, M., Supriadi, S., Yulfitra, Y., \& Barita, B. (2019). Perancangan Mesin Pengaduk Pakan Ternak Sapi dengan Sistem Sirkulasi Vertikal Menggunakan Screw Driver. MEKANIK: Jurnal Ilmiah Teknik Mesin, 5(1).

Dewanti, R., \& Sihombing, G. (2012). Analisis pendapatan usaha peternakan ayam buras (Studi kasus di Kecamatan Tegalombo, Kabupaten Pacitan). Buletin Peternakan, $36(1), 48-56$.

Ella, A., Nurhayu, A., \& Pasambe, D. (2016). Pemanfaatan Tepung Jerami Padi Dan Keong Emas (Pomacea canaliculata) Sebagai Campuran Pakan Itik Sedang Bertumbuh. Jurnal Agrisistem, 12(2), 179-185.

Fadly, Z. A. (2016). Pengaruh penambahan keong emas (pomacea canaliculata) dalam pakan komersial terhadap pertumbuhan ikan lele dumbo (clarias gariepinus).

Gusnadi, G., \& Razak, N. R. (2018). Pengaruh Penambahan Tepung Keong Mas (Pomacea canaliculata lamarck) Pada Pakan Terhadap Performa Ayam Akusi. Agrominansia, $3(1), 49-57$.

Hendrawati, R. (2011). Pemanfaatan Limbah Produksi Pangan Dan Keong Emas (Pomacea Canaliculata) Sebagai Pakan Untuk Meningkatkan Pertumbuhan Ikan Lele Dumbo (Clarias Gariepinus).

Kusumawati, T. (2019). Potensi cangkang telur ayam sebagai bahan tambahan dalam pembuatan onde onde mini ketawa. Skripsi, Universitas Sanata Dharma, Yogyakarta.

Majedi, M. A., Mahanani, E. S., \& Triswari, D. (2013). Perbedaan efektivitas penambahan bubuk cangkang telur ayam ras dengan ayam kampung terhadap durasi perdarahan (in vivo). Insisiva Dental Journal: Majalah Kedokteran Gigi Insisiva, 2(1).

Rahmawati, I. R., Muksin, M., \& Rizal, R. (2016). Peran dan Kinerja Penyuluh Pertanian dalam Memberdayakan Peternak Ayam Petelur di Kabupaten Jember, Provinsi Jawa Timur. Jurnal Penyuluhan, 12(2), 183-189.

Rahmawati, W. A., \& Nisa, F. C. (2014). Fortifikasi kalsium cangkang telur pada pembuatan cookies (kajian konsentrasi tepung cangkang telur dan baking powder)[in press Juli 2015]. Jurnal Pangan dan Agroindustri, 3(3).

Ratnasari, R., Sarengat, W., \& Setiadi, A. (2015). Analisis pendapatan peternak ayam broiler pada sistem kemitraan di Kecamatan Gunung Pati Kota Semarang. Animal Agriculture Journal, 4(1), 47-53.

Susanto, T. N., Atmono, A., \& Natalina, N. (2017). Pemanfaatan Limbah Cangkang Telur Ayam Sebagai Media Adsorben Dalam Penurunan Kadar Logam Kromium Heksavalen (Cr6+) Pada Limbah Cair Industri Elektroplating. Ecolab, 11(1), 27-31.

Utomo, B., Sucahya, P. K., Romadlona, N. A., Robertson, A. S., Aryanty, R. I., \& Magnani, R. J. (2021). The impact of family planning on maternal mortality in Indonesia: what future contribution can be expected? Population Health Metrics, 19(1), 1-13. 